\title{
Difficulties of familes in caring for children and adolescents with mental disorders: an integrative review*
}

\author{
DIFICULDADES DAS FAMÍLIAS NO CUIDADO À CRIANÇA E AO ADOLESCENTE COM \\ TRANSTORNO MENTAL: UMA REVISÃO INTEGRATIVA
}

\author{
DIFICULTADES DE LAS FAMILIAS EN LAATENCIÓN A NIÑOS Y JÓVENES CON TRASTORNO \\ MENTAL: UNA REVISIÓN INTEGRAL
}

\section{Lany Leide de Castro Rocha Campelo', Sarah Maria Esequiel Costa ${ }^{2}$, Luciana de Almeida Colvero}

\begin{abstract}
Objective: To identify the difficulties of families with children and/or adolescents with mental disorder. Method: This is an integrative review. In December 2013, an electronic search was performed on Latin American Caribbean Literature on Health Sciences databases (LILACS) and on Electronic Medicus Index of the National Library of Medicine (MEDLINE) indexed in the Health Virtual Library (BVS) using a combination of descriptors and boolean operators as follows: mental disorders and child or adolescent and caregivers and/not health staff. Results: 557 studies were identified, of which 15 were selected for this study. The findings indicated difficulties related to the care for or to interaction with children/adolescents with mental disorder. Conclusion: The studies revealed difficulties related to everyday practices of care and feelings expressed during care practices, as well as in relationships with children or adolescents with mental disorder.
\end{abstract}

\section{DESCRIPTORS}

Child

Adolescent

Mental disorders

Family

Mental Health Services

Review

\section{RESUMO}

Objetivo: Identificar as dificuldades das famílias de crianças ou adolescentes com transtornos mentais. Método: Trata-se de uma revisão integrativa realizada nas bases de dados da Literatura Latino-Americana do Caribe em Ciências da Saúde (LILACS) e no Index Medicus Eletrônico da National Library of Medicine (MEDLINE) indexadas na Biblioteca Virtual em Saúde (BVS) utilizando a combinação dos descritores e operadores booleanos transtornos mentais and criança or adolescente and cuidadores and/not pessoal de saúde, em dezembro de 2013. Resultados: Foram identificados 557 estudos, dos quais 15 foram selecionados para este estudo. Os achados evidenciaram dificuldades relacionadas ao cuidado ou convívio com crianças ou adolescentes com transtorno mental. Conclusão: Foram evidenciadas dificuldades relacionadas às práticas cotidianas e aos sentimentos manifestos durante o convívio e o cuidado de crianças ou adolescentes com transtornos mentais.

DESCRITORES
Criança
Adolescente
Transtornos mentais
Família
Serviços de Saúde Mental
Revisão

\section{RESUMEN}

Objetivo: Identificar las dificultades de las familias con niños y/o adolescentes con desórdenes mentales. Método: Se trata de una revisión integradora. Una búsqueda electrónica se realizó en diciembre de 2013, en la base de datos de la literatura caribeña Latinoamericano de Ciencias de la Salud (LILACS) y en el Índice de Electronic Medicus de la Biblioteca Nacional de Medicina (MEDLINE) indexados en la Biblioteca Virtual en Salud (BVS), utilizando combinación de descriptores y operadores booleanos transtornos mentales and niño and adolescentes and cuidadores and/not personal de salud. Resultados: Se identificaron 557 estudios, de los cuales 15 fueron considerados para este estudio. Los hallazgos indican dificultades relacionadas con la atención o estar con los niños o adolescentes con trastornos mentales. Conclusión: Se evidenciaron las dificultades relacionadas con las prácticas cotidianas y con los sentimientos durante la atención de quien vive con un niño o adolescente con trastornos mentales.

DESCRIPTORES
Niño
Adolescente
Trastornos mentales
Família
Servicios de Salud Mental
Revisión

* From the dissertation "Care for families in a child psychosocial care center: education actions in health from the relatives' point of view", School of Nursing, University of São Paulo, 2013. ' Master's degree in Nursings, School of Nursing, University of São Paulo, São Paulo, SP, Brazil. ${ }^{2}$ Clinical psychologist, Member of the Study Group in Maternal-Child and Psychiatric Nursing , School of Nursing, University of São Paulo, São Paulo, SP, Brazil. ${ }^{3}$ Full professor, Department of Maternal-Child and Psychiatric Nursing, School of Nursing, University of São Paulo, São Paulo, SP, Brazil 


\section{INTRODUCTION}

Problems related to mental health that occur during childhood and adolescence are frequent and have a major impact on the present and future of these people and of society as a whole ${ }^{(1)}$.

Throughout human development, mental health problems have occurred as a result of multiple and varied precursors that include biological, social and psychological aspects, as well as economic and demographic factors such as gender and age, serious threats such as conflicts and disasters, the presence of a severe physical disease, and family environment, although they may occur as a result of the absence of opportunities ${ }^{(2)}$.

The occurrence of a severe, long-term illness, such as mental disease, has great impact on the family, as it imposes situations related to symptoms, which the family will not always be ready to deal with, such as lack of emotional control and crises of aggressiveness and restlessness, which destabilize the whole family structure ${ }^{(3)}$.

Caring for a relative with mental health problems can be considered a stressful life event, especially when symptoms are severe and put the person's health at risk $^{(4)}$. Care becomes a daily need and coexistence can give rise to feelings such as shame and embarrassment about the person's behavior in public, as well as guilt about the appearance of the disease and fear of situations that are more difficult to control, which hinder the relationship between the family and the mentally ill person ${ }^{(5)}$.

When the mentally ill person is a child or an adolescent, the increased available time that is required results in drastic changes in the family routine, way of life, relationship with work, relationship with other children, couple relationship, expense control and even daily life ${ }^{(6)}$.

Families with mentally ill members experience severe damage on the psychological level, as well as on the material and personal levels ${ }^{(7)}$. The historical process of deinstitutionalization triggered by psychiatric reform in Brazil resulted in changes in the mental health care model, not only for people who have mental disorders but also for their families. Therefore, families became both a point of support for family care and the object of intervention services, according to World Health Organization recommendations in the field of mental health ${ }^{(8)}$.

To achieve effective interventions, it is necessary to acknowledge the real needs of these families. Considering the range of difficulties arising from living with different symptoms of mental disorders that affect children and adolescents, this study tried to identify the main difficulties encountered by families with mentally ill children or adolescents.

\section{METHOD}

This is an integrative review that provided a synthesis of several published studies, which allowed for the creation of new knowledge based on results presented by previous research. The review consisted of six steps ${ }^{(9)}$ : 1) identification of the topic and definition of the problem, with emphasis on the importance of the matter for health and nursing; 2) establishment of inclusion and exclusion criteria for studies in the bibliographic search; 3) categorization of relevant information from selected studies; 4) evaluation of studies included in the integrative review; 5) interpretation of results, by comparing results obtained from research with previous theoretical knowledge; and 6) presentation of the review and synthesis of data obtained.

The topic difficulties of families with mentally ill children or adolescents guided the elaboration of the question for study: What are the difficulties encountered by families with mentally ill children or adolescents?

An electronic search was performed in December 2013 in a number of databases: the Latin American Caribbean Literature on Health Sciences database (LILACS); the Electronic Medicus Index of the National Library of Medicine (MEDLINE); IBECS (Spain); and CENTRAL -- Record of controlled clinical trials. All are indexed in the Virtual Health Library (VHL).

Research on the databases were performed using standardized vocabulary oriented toward the question of study in order to describe, organize and provide access to relevant information from a vast amount of data, without any restriction on period of publication. A tool named DeCS (Descriptors in Health Sciences) was used to find descriptors. The combination of selected descriptors was done by means of the Boolean operators $O R, A N D$ and NOT. The research strategy was as follows: mental disorders and child or adolescent and caregivers and/not health staff.

The inclusion criteria were: primary studies in Portuguese, English or Spanish; available in the databases in their entirety and for free; presents or discusses the difficulties encountered by families in care for or coexistence with a mentally ill child or adolescent; includes relatives of children or adolescent with severe or persistent mental disorders as subjects (fathers/mothers[biological or adoptive], uncles/aunts, grandparents, siblings). The following studies were excluded: secondary studies; theses or dissertations; studies whose main subjects did not include relatives of children/adolescents; studies in which the children/adolescents had intellectual disabilities or neurological diseases.

The choice of articles was made by the authors after reading titles, keywords and abstracts. After this pre-selection process, copies of complete texts were obtained so the articles 
could be read through and inclusion and exclusion criteria applied. The next step was to enter data from the articles that complied with the selection criteria in a chart containing the following information: title, objectives, method/participants, difficulties encountered, database and country of origin.

\section{RESULTS}

Five hundred fourteen studies were identified in the MEDLINE database, 12 studies in LILACS, 5 in IBECS (Spain) and 25 in CENTRAL, totaling 557 studies. Of all the studies, 34 were read through. In the analysis of these publications, it was observed that 23 were not specifically related to the guiding question or did not meet the inclusion criteria, which left a total for the final sample of 11 works that were included in this study.

Chart 1 shows the distribution of works according to the year of publication in the mentioned databases, with a greater number of works in 2011 with 4 studies, followed by 2008 with 3 studies, and 1999, 2006, 2012 and 2013 with one study each. Regarding research methodology, 5 studies were qualitative and 6 were quantitative. As for the country of origin, the United States prevailed, as well as the English language. Study subjects were mainly mothers, followed by parents, siblings, grandmothers, uncles/aunts and others.

Chart 1 - Characterization of analyzed articles and difficulties identified

\begin{tabular}{|c|c|c|c|c|c|}
\hline Title & Objectives & \begin{tabular}{|c|} 
Method/Par- \\
ticipants
\end{tabular} & Difficulties identified & Database & $\begin{array}{l}\text { Country } \\
\text { of origin }\end{array}$ \\
\hline $\begin{array}{l}\text { Geraghty K, McCann K, King } \\
\text { R, Eichmann K. Sharing the } \\
\text { load: parents and carers talk to } \\
\text { consumer consultants at a child } \\
\text { and youth mental health inpatient } \\
\text { unit. Int J Ment Health Nurs. } \\
\text { 2011;20(4):253-62(10). }\end{array}$ & $\begin{array}{l}\text { To investigate how } \\
\text { parents deal with the } \\
\text { support of partners } \\
\text { when available. }\end{array}$ & $\begin{array}{l}\text { Qualitative } \\
\text { study with } \\
50 \text { caregivers } \\
\text { (41 parents, } 7 \\
\text { grandparents, } \\
5 \text { fathers, } 3 \\
\text { siblings) }\end{array}$ & $\begin{array}{l}\text { - Concern and anxiety } \\
\text { - Loss and bereavement } \\
\text { - Loss of a specific opportunity } \\
\text { - Anger and frustration resulting from communi- } \\
\text { cation problems within the team } \\
\text { - Concern with the impact of the disease on } \\
\text { other children within the family } \\
\text { - Isolation from the family } \\
\text { - Difficulty in managing the parental role } \\
\text { - Costs } \\
\text { - Difficulty in finding a place to stay during } \\
\text { hospitalization of children/adolescents } \\
\text { - Need to leave work }\end{array}$ & MEDLINE & Australia \\
\hline $\begin{array}{l}\text { Oruche UM, Gerkensmeyer J, } \\
\text { Stephan L, Wheeler CA, Hanna } \\
\text { KM. The described experience } \\
\text { of primary caregivers of children } \\
\text { with mental health needs. Arch } \\
\text { Psychiatr Nurs. 2012;26(5):382- } \\
\text { 91(11). }\end{array}$ & $\begin{array}{l}\text { To describe the } \\
\text { challenges faced by } \\
\text { caregivers of children } \\
\text { with mental health } \\
\text { needs }\end{array}$ & \begin{tabular}{|l|} 
Qualitative \\
study with \\
20 female \\
caregivers \\
(14 biological \\
mothers, \\
5 adoptive \\
mothers and 1 \\
grandmother) \\
\end{tabular} & $\begin{array}{l}\text { - Difficulty in having access to care } \\
\text { - Stigma and guilt } \\
\text { - Fear for the safety of their children and other's } \\
\text { - Difficulty in meeting their own needs } \\
\text { - Relatives that were caregivers felt responsible, } \\
\text { overloaded and exhausted }\end{array}$ & MEDLINE & $\begin{array}{l}\text { United } \\
\text { States }\end{array}$ \\
\hline $\begin{array}{l}\text { Knock J, Kline E, Schiffman J, } \\
\text { Maynard A, Reeves G. Burdens } \\
\text { and difficulties experienced } \\
\text { by caregivers of children and } \\
\text { adolescents with schizophrenia- } \\
\text { spectrum disorders: a qualitative } \\
\text { study. Early Interv Psychiatry. } \\
\text { 2011;5(4):349-54(12). }\end{array}$ & $\begin{array}{l}\text { To investigate } \\
\text { burdens and difficul- } \\
\text { ties experienced by } \\
\text { caregivers of children } \\
\text { and adolescents with } \\
\text { schizophrenia-spec- } \\
\text { trum disorders }\end{array}$ & $\begin{array}{l}\text { Qualitative } \\
\text { study with } 10 \\
\text { caregivers: } \\
8 \text { parents, } \\
1 \text { uncle, } 1 \\
\text { brother ( } 8 \\
\text { women and } \\
10 \text { men) } \\
\end{array}$ & $\begin{array}{l}\text { - Emotional stress } \\
\text { - Loss of a regular life and parenthood } \\
\text { - Difficulties related to mental health services } \\
\text { - Concern with how to deal with other children } \\
\text { in the household while maintaining discipline } \\
\text { and household routine } \\
\text { - Difficulties related to specific matters of the } \\
\text { development of children and adolescents }\end{array}$ & MEDLINE & $\begin{array}{l}\text { United } \\
\text { States }\end{array}$ \\
\hline $\begin{array}{l}\text { Machineski GG, Schneider JF, } \\
\text { Camatta MW. Living situation } \\
\text { of relatives of child psychosocial } \\
\text { care center users. Rev Gaúcha } \\
\text { Enferm. 2013;34(1):126-32(13). }\end{array}$ & $\begin{array}{l}\text { To understand the } \\
\text { living situation of } \\
\text { relatives of child psy- } \\
\text { chosocial care center } \\
\text { (CAPS) users }\end{array}$ & $\begin{array}{l}\text { Qualitative } \\
\text { study with } 11 \\
\text { relatives }\end{array}$ & $\begin{array}{l}\text { - Lack of direct contact with CAPS profession- } \\
\text { als } \\
\text { - Altered behavior of relatives in the social } \\
\text { sphere }\end{array}$ & LILACS & Brazil \\
\hline $\begin{array}{l}\text { Sung V, Hiscock H, Sciberras } \\
\text { E, Efron D. Sleep problems in } \\
\text { children with attention-deficit/ } \\
\text { hyperactivity disorder: preva- } \\
\text { lence and the effect on the child } \\
\text { and family. Arch Pediatr Adolesc } \\
\text { Med. 2008;162(4):336-42(15). }\end{array}$ & $\begin{array}{l}\text { To determine the } \\
\text { prevalence of sleep } \\
\text { problems in children } \\
\text { with attention-deficit } \\
\text { disorders and the } \\
\text { effect on the children } \\
\text { and families: quality } \\
\text { of life, daily routine, } \\
\text { school attendance, } \\
\text { mental health, work } \\
\text { and functioning of } \\
\text { families. }\end{array}$ & $\begin{array}{l}\text { Cross-sec- } \\
\text { tional study } \\
\text { with } 239 \\
\text { caregivers }\end{array}$ & $\begin{array}{l}\text { - Loss in quality of life, family functioning and } \\
\text { ability to care for the children }\end{array}$ & MEDLINE & $\begin{array}{l}\text { United } \\
\text { States }\end{array}$ \\
\hline
\end{tabular}




\begin{tabular}{|c|c|c|c|c|c|}
\hline Title & Objectives & $\begin{array}{l}\text { Method/Par- } \\
\text { ticipants }\end{array}$ & Difficulties identified & Database & $\begin{array}{l}\text { Country } \\
\text { of origin }\end{array}$ \\
\hline $\begin{array}{l}\text { Lecavalier L, Leone S, Wiltz J. } \\
\text { The impact of behaviour prob- } \\
\text { lems on caregiver stress in young } \\
\text { people with autism spectrum } \\
\text { disorders. J Intellect Disabil Res. } \\
\text { 2006;50(3):172-83(16). }\end{array}$ & $\begin{array}{l}\text { To examine the } \\
\text { impact of behav- } \\
\text { ior problems on } \\
\text { caregiver stress in a } \\
\text { large group of young } \\
\text { people with autism } \\
\text { spectrum disorders. } \\
\end{array}$ & $\begin{array}{l}\text { Quantitative } \\
\text { study with } \\
293 \text { parents } \\
\text { and teachers } \\
(86 \% \text { moth- } \\
\text { ers) }\end{array}$ & - Caregiver stress & MEDLINE & $\begin{array}{l}\text { United } \\
\text { Kingdom }\end{array}$ \\
\hline $\begin{array}{l}\text { Lin LY. Factors associated with } \\
\text { caregiving burden and maternal } \\
\text { pessimism in mothers of adoles- } \\
\text { cents with an autism spectrum } \\
\text { disorder in Taiwan. Occup Ther } \\
\text { Int. 2011;18(2):96-105(18). }\end{array}$ & $\begin{array}{l}\text { To analyze the } \\
\text { characteristics of } \\
\text { adolescents with } \\
\text { autism spectrum } \\
\text { disorders associ- } \\
\text { ated with caregiving } \\
\text { burdens and maternal } \\
\text { pessimism and assess } \\
\text { the extent to which } \\
\text { the characteristics of } \\
\text { adolescents with ASD } \\
\text { predicts maternal } \\
\text { pessimism. }\end{array}$ & $\begin{array}{l}\text { Quantitative } \\
\text { study with } 50 \\
\text { mothers }\end{array}$ & $\begin{array}{l}\text { - High rates of caregiving burdens and maternal } \\
\text { pessimism }\end{array}$ & MEDLINE & England \\
\hline $\begin{array}{l}\text { Gerkensmeyer JE, Perkins SM, } \\
\text { Scott EL, Wu J. Depressive } \\
\text { symptoms among primary care- } \\
\text { givers of children with mental } \\
\text { health needs: mediating and } \\
\text { moderating variables. Arch } \\
\text { Psychiatr Nurs. } 2008 ; 22(3): 135- \\
46(19) \text {. }\end{array}$ & $\begin{array}{l}\text { To analyze depressive } \\
\text { symptoms among } \\
\text { primary caregivers of } \\
\text { children with severe } \\
\text { mental disorders }\end{array}$ & $\begin{array}{l}\text { Cross-sec- } \\
\text { tional study } \\
\text { with } 155 \\
\text { parents ( } 81 \% \\
\text { biological } \\
\text { mothers; } \\
8 \% \text { adoptive } \\
\text { mothers; } 7 \% \\
\text { grandparents; } \\
1 \% \text { fathers) }\end{array}$ & $\begin{array}{l}\text { - High rates of depressive symptoms among } \\
\text { caregivers }\end{array}$ & MEDLINE & $\begin{array}{l}\text { United } \\
\text { States }\end{array}$ \\
\hline $\begin{array}{l}\text { Kilmer RP, Cook JR, Taylor C, } \\
\text { Kane SF, Clark LY. Siblings of } \\
\text { children with severe emotional } \\
\text { disturbances: risks, resources, } \\
\text { and adaptation. Am J Horthopsy- } \\
\text { chiatr. 2008;78(1):1-10(20). }\end{array}$ & $\begin{array}{l}\text { To analyze risks, } \\
\text { resources and adapta- } \\
\text { tion among siblings } \\
\text { of children with } \\
\text { severe emotional } \\
\text { disturbances in order } \\
\text { to develop family } \\
\text { systems of central- } \\
\text { ized care. }\end{array}$ & $\begin{array}{l}\text { Longitudinal } \\
\text { study with } 34 \\
\text { families }\end{array}$ & $\begin{array}{l}\text { - Siblings of children with emotional distur- } \\
\text { bances showed troublesome behaviors }\end{array}$ & MEDLINE & $\begin{array}{l}\text { United } \\
\text { States }\end{array}$ \\
\hline
\end{tabular}

\section{DISCUSSION}

The results presented show that the difficulties encountered by relatives of children with mental disorders are in line with those found in relatives of adults with mental disorders. However, the difficulties of caring for children become more pronounced as a result of their dependence on adults, which is specific to this stage of life, such as matters related to physical, mental and social development ${ }^{(21)}$.

Families of children or adolescents with mental disorders experience difficulties in many aspects of daily life. The analysis of the studies allowed for the identification of difficulties in living with children or adolescents at home, in health care services and at school, as well as in feelings aroused in caregivers by caregiving burdens.
The difficulties begin in the search for the understanding of what is wrong with the child or adolescent, that is, the reason for their different behavior. It is difficult for parents to identify whether the condition presented by the child is a characteristic sign of disease or simply their own behavior. When a diagnosis of mental disorder is made, it is initially difficult for parents to understand or accept the information provided by doctors or health professionals, often because stress levels at the moment of confirmation prevent them from understanding and assimilating the information ${ }^{(22-23)}$.

Care for a child with chronic disease is a long, tough process for the whole family; in addition to being in a permanent state of alertness, they need to give specific and various types of care, resulting in emotional suffering and intense physical strain. In order to provide care, the family 
must review its structure and functioning mode, learn to deal with the child's new needs, review the responsibilities for the new tasks, and make decisions on who will be in charge of care ${ }^{(22)}$; in brief, they need to drastically change their routine.

When it comes to mental disorders, the burdens experienced by families are innumerable and they often result in burdens for the caregivers, who have the task of helping with the daily routine (such as giving medications, monitoring treatment, taking care of personal hygiene and nutrition) and supervising problematic behaviors of the mentally ill(24-25). These tasks require knowledge and availability, that is, time to devote themselves to care, in addition to physical fitness and emotional preparation for dealing with various situations.

This research highlighted several difficulties. Regarding knowledge, two studies ${ }^{(10-11)}$ highlighted the difficulties of parents in understanding the medical terms used to inform them of the diagnoses of the children. These studies also emphasized the pressure families are under to quickly learn about the diagnoses. To do so, they have to look on their own for information about the treatment needs and resources.

In the search for mental health services that meet the needs of children or adolescents, difficulties related to accessibility were observed, as access to mental health services becomes particularly difficult when children are having seizures ${ }^{(11-12)}$. Difficulties were also found regarding the suitability of the services when it comes to safety and the impact of negative experiences of children/adolescents and family members with health staff(10).

Issues related to lack of support and results from public policies and lack of welcoming attitudes from professionals were mentioned in three studies. Lack of support was also found in the family environment, when other family members did not understand the disease and saw the young people as manipulative ${ }^{(10)}$. This was also found in the health and education services spheres, where inadequate training of professionals stood out $\mathrm{t}^{(10-11,13)}$.

In one of the articles, care was described as an obligation and a major responsibility, especially for mothers and other female relatives, who try to balance care needs with family, work and other commitments ${ }^{(14)}$. This burden can result in overload as relatives stand back and caregivers become the only people responsible for care ${ }^{(26)}$.

The isolation that caregivers and mentally ill people are subject to is the result of a stigma imposed on mentally ill people and on relatives and friends. In one of the analyzed studies, the stigma was associated with fear of rejection and fear that the community did not accept that the child had a health problem rather than a problem of behavior. In another study, it was found that isolation can occur when caregivers are not supported by families, or when caregivers lose contact with social networks and ties created within the workplace to devote themselves to caring for children or adolescents with mental disorders. In view of this, caregiving sometimes means sacrificing personal and professional growth, quitting work, bearing emotional pain and becoming socially isolated ${ }^{(11)}$.

To be available means to have time to provide care. Keeping a job and caring for a child with a mental disorder was pointed out in two articles as an impossible task by many caregivers due to the difficulty of being on time or to high needs of children, making care very expensive ${ }^{(11,15)}$.

Physical and emotional strain was also mentioned. Care for children or adolescents with mental disorders was mentioned as being physically and emotionally demanding, as it requires permanent concern and surveillance from caregivers, who must be reachable at all times. Monitoring must be permanent in order to avoid harmful behavior by children, toward themselves and others, as well as the constant search for necessary health services. This monitoring must be associated with compliance with other commitments and obligations, such as caring for other children, working and maintaining marital relationships. These tasks were described as physically and psychologically exhausting, and this had an impact on caregivers' ability to care for themselves ${ }^{(11)}$.

Caregiver stress was a topic present in four articles; it was mainly associated with conduct problems and lack of social behavior, such as breaking of rules, disruptive and challenging attitudes, disobedience and aggressiveness from children or adolescents ${ }^{(16)}$; more communication and medical consultations; the need for caregivers to think about matters related to the children's future ${ }^{(17)}$; and a lower degree of functional independence of the children or adolescents ${ }^{(18)}$.

Care for mentally ill children or adolescents was associated with the advent of mental health problems. Greater risks of depression were associated with less social support, lower income, less emotional support and dissatisfaction with family functioning ${ }^{(19)}$. Higher rates of psychiatric morbidity were associated with children's low ability to function, the high degree of injury suffered by caregivers, high levels of overload among caregivers, and low educational levels among patients ${ }^{(14)}$.

Another study also revealed that a considerable proportion of siblings had problematic levels of competence and behavior, which suggests that living with children with mental disorders can result in damage to the mental health of other family members ${ }^{(20)}$.

Given this situation, families commonly experience feelings of shame and embarrassment as a result of mentally ill people's behavior in public; guilt about the emergence of the disease; and fear of aggressive attitudes ${ }^{(5)}$, in addition to feelings of powerlessness, fragility and frustration regarding expectations of mentally ill relatives ${ }^{(27)}$. In the selected studies, feelings of powerlessness were re- 
lated to responsibilities for care and lack of support from partners, which sometimes led caregivers to take extreme measures to lessen their burdens, such as the use of sleeping pills, or to adopt risky behaviors, such as the use of alcohol to deal with the situation ${ }^{(11)}$.

Feelings of guilt regarding the emergence of the disease is one of the most visible features in the lives of these families, which bring up countless questions regarding mistakes made in the upbringing of the children, resulting in permanent internal conflict in the attempt to understand the problems ${ }^{(5)}$. Feelings of guilt were present in two articles, and they were associated with concern of parents about inability to care for the children or the perception that they had contributed to the development of the disease. Parents felt guilty for not always being present when the children needed them, due to other commitments such as work ${ }^{(10)}$.

Claiming that the disease and behavior problems of the children and relatives resulted from something that went wrong in their daily life, health professionals tended to indicate that caregivers were responsible for this, which also aroused feelings of responsibility ${ }^{(10-11)}$. Feelings of fear were described in one study ${ }^{(11)}$, and they were associated with the dangerous nature of the children's behaviors, and fears of parents regarding their children's physical safety, as well as the safety of themselves and others.

In four studies, concern was always present, and it was related to the safety of services, learning adequate practices, or even concern that the children were always being cared for in the best way possible by health servic$\mathrm{es}^{(10)}$. The future was also mentioned, especially regarding options for employment for the mentally ill(10,18) and the well-being of relatives, including access to health care services by spouses and other children, as well as the maintenance of household routines ${ }^{(12)}$.

Feelings of loss were mentioned in one study and they were associated with specific situations, such as loss of educational opportunities, attending an important gym competition, going to school or camp, or learning to drive ${ }^{(10)}$.

\section{REFERENCES}

1. Duarte CS, Couto MCV, Graeff-Martins AS, Pegoraro R, Dahl C, Cavalcanti MT. A rede pública ampliada de atenção à saúde mental da criança e do adolescente: estudo piloto em quatro localidades do estado do Rio de Janeiro. In: Laurindsen-Ribeiro E, Tanaka OU, organizadores. Atenção em saúde mental para crianças e adolescentes no SUS. São Paulo: Hucitec; 2010. p. 280-302.

2. Sá DGF, Bordin IAS, Martin D, Paula CS. Fatores de risco para problemas de saúde mental na infância/adolescência. Psicol Teor Pesq. 2010;26(4):643-52.
The studies showed a series of difficulties experienced by families of children or adolescents with mental disorders in different areas of daily life. It is essential to give them visibility in all presented aspects, so we can understand and establish ways of caring that are suitable to the needs of each family.

\section{CONCLUSION}

An analysis of the literature allowed us to see that caregivers still have limited knowledge and conditions for providing access to more efficient care services for children and adolescents with mental disorders. This context is directly related to a series of factors identified in the research, such as socioeconomic and educational matters and limited care strategies provided by mental health services. Such services are also responsible for providing information about preventive factors and health promotion, as is ensured by law in the fundamental rights of children and adolescents.

However, it is important to consider the peculiarities of each case of caregivers, children and adolescents. The knowledge and internal (emotional) and external (services) resources available to caregivers affect both patient health and the evolution of the disorder. This fact confirms information revealed by the research, which unfortunately shows the gap between demands from children, adolescents and relatives, and care provided by health services.

To develop interdisciplinary vision and practice, in collaboration with caregivers and mental health managers, with clearly defined and dynamic strategies, represents a possibility of reducing damage and suffering in view of complex demands that are difficult to meet with simple solutions. This implies critical observation of the services, conduct and strategies of the professionals involved, as they are directly responsible, along with families, for caring for these children and adolescents, and they must be capable of having families and mental health services closer to each other.

An adequate welcome is essential to establishing close relationships, which is very important for treatment and its continuity. In view of this, proper training of health professionals is essential.

3. Sant'Ana MM, Pereira, VP, Borenstein MS, Silva AL. O significado de ser familiar do portador de transtorno mental. Texto Contexto Enferm. 2011;20(1): 50-8.

4. Athay MM. Satisfaction with Life Scale (SWLS) in caregivers of clinically-referred youth: psychometric properties and mediation analysis. Adm Policy Ment Health. 2012;39(12):41-50. 
5. Vicente JB, Mariano PP, Buriola AA, Paiano M, Waidman MAP, Marcon SS. Aceitação da pessoa com transtorno mental na perspectiva dos familiares. Rev Gaúcha Enferm. 2013;34(2):54-61.

6. Goés FGB, La Cava AM. Práticas educativas em saúde do enfermeiro com a família da criança hospitalizada. Rev Eletr Enferm [Internet]. 2009 [citado 2014 fev. 17];11(4):942-51. Disponível em: http://www.fen.ufg.br/fen_revista/v11/n4/ pdf/v11n4a20.pdf

7. Schein S, Boeckel MG. Análise da sobrecarga familiar no cuidado de um membro com transtorno mental. Saúde Transf Soc. 2012;3(2):32-42.

8. Telles HPRS. A criança nos discursos da saúde mental: um percurso histórico a partir de recomendações para práticas públicas. In: Laurindsen-Ribeiro E, Tanaka OU, organizadores. Atenção em saúde mental para crianças e adolescentes no SUS. São Paulo: Hucitec; 2010. p. 131-43.

9. Mendes KDS, Silveira RCCP, Galvão CM. Revisão integrativa: método de pesquisa para a incorporação de evidências na saúde e na enfermagem integrative literature. Texto Contexto Enferm. 2008;17(4):758-64.

10. Geraghty K, McCann K, King R, Eichmann K. Sharing the load: parents and carers talk to consumer consultants at a child and youth mental health inpatient unit. Int J Ment Health Nurs. 2011;20(4): 253-62.

11. Oruche UM, Gerkensmeyer J, Stephan L, Wheeler CA, Hanna KM. The described experience of primary caregivers of children with mental health needs. Arch Psychiatr Nurs. 2012;26(5):382-91.

12. Knock J, Kline E, Schiffman J, Maynard A, Reeves G. Burdens and difficulties experienced by caregivers of children and adolescents with schizophrenia-spectrum disorders: a qualitative study. Early Interv Psychiatry. 2011;5(4): 349-54.

13. Machineski GG, Schneider JF, Camatta MW. O tipo vivido de familiares de usuários de um centro de atenção psicossocial infantil. Rev Gaúcha Enferm. 2013;34(1):126-32.

14. Okewole A, Dada MU, Ogun O, Bello-Mojeed M, Usoh T. Prevalence and correlates of psychiatric morbidity among caregivers of children and adolescents with neuropsychiatric disorders in Nigeria. Afr J Psychiatry (Johannesbg). 2011;14(4):306-9.

15. Sung V, Hiscock $H$, Sciberras E, Efron D. Sleep problems in children with attention-deficit/hyperactivity disorder: prevalence and the effect on the child and family. Arch Pediatr Adolesc Med. 2008;162(4): 336-42.
16. Lecavalier L, Leone S, Wiltz J. The impact of behaviour problems on caregiver stress in young people with autism spectrum disorders. J Intellect Disabil Res. 2006;50(Pt 3):172-83

17. McDonald TP, Poertner J, Pierpont J. Predicting caregiver stress: an ecological perspective. Am J Orthopsychiatry. 1999;69(1):100-9.

18. Lin LY. Factors associated with caregiving burden and maternal pessimism in mothers of adolescents with an autism spectrum disorder in Taiwan. Occup Ther Int. 2011;18(2):96-105.

19. Gerkensmeyer JE, Perkins SM, Scott EL. Depressive symptoms among primary caregivers of children with mental health needs: mediating and moderating variables. Arch Psychiatr Nurs. 2008;22(3):135-46.

20. Kilmer RP, Cook JR, Taylor C, Kane SF, Clark LY. Siblings of children with severe emotional disturbances: risks, resources, and adaptation. Am J Orthopsychiatry. 2008;78(1):1-10.

21. Bee H, Boyd D. A criança em desenvolvimento. $12^{\text {a }}$ ed. Porto Alegre: Artmed; 2011.

22. Damião EBC, Ângelo M. A experiência da família em ter uma criança com doença crônica. In: Gualda DMR, Bergamasco $\mathrm{RB}$, organizadoras. Enfermagem, cultura e o processo saúdedoença. São Paulo: Ícone; 2004. p. 119-34.

23. Schutsky K, Ouyang M, Castelino CB, Zhang L, Thomas SA. Stress and glucocorticoids impair memory retrieval via $ß 2$ adrenergic, Gi/o-coupled suppression of cAMP signaling. J Neurosci. 2011;31(40):14172-81.

24. Schein S, Gonçalves BM. Análise da sobrecarga familiar no cuidado de um membro com transtorno mental. Saúde Transf Soc. 2012;3(2):32-42.

25. Cardoso L, Galera SAF, Vieira MV. O cuidador e a sobrecarga do cuidado à saúde de pacientes egressos de internação psiquiátrica. Acta Paul Enferm. 2012;25(4):517-23.

26. Moreno V. Familiares de portadores de transtorno mental: vivenciando o cuidado em um Centro de Atenção Psicossocial. Rev Esc Enferm USP. 2009;43(3):566-72.

27. Borba LO, Paes MR, Guimarães AN, Labronici LM, Maftum MA. The family and the mental disturbance carrier: dynamics and their family relationship. Rev Esc Enferm USP [Internet]. 2011 [cited 2014 Mar 15];45(2):442-9. Available from: http://www.scielo.br/pdf/reeusp/v45n2/en_v45n2a19.pdf
Correspondence: Luciana de Almeida Colvero

Departamento de Enfermagem Materno-Infantil e Psiquiátrica Escola de Enfermagem da USP

Av. Dr. Enéas de Carvalho Aguiar, 419 - Cerqueira César

CEP 05403-000 - São Paulo, SP, Brasil

E-mail: lucix@usp.br 